\title{
Leptoboea multiflora subsp. grandifolia (Gesneriaceae), a new record for India
}

\author{
Alappatt J.P. \\ Department of Environment \& Forests, Forest Training Institute, \\ Wimberlygunj, Andaman \& Nicobar Islands - 744 206, India. \\ E-mail: jojualappatt@yahoo.com
}

\begin{abstract}
Leptoboea multiflora (C.B.Clarke) Benth. ex Gamble subsp. grandifolia B.L.Burtt is reported for the first time from the Andaman and Nicobar Islands, India. This subspecies, so far considered as endemic to Thailand, was collected from inland evergreen forests of South Andaman Island. A detailed description and photographs are provided to facilitate easy identification in the field.
\end{abstract}

Keywords: Andaman Islands, Gesneriaceae, India, Leptoboea multiflora subsp. grandifolia, New record.

\section{Introduction}

Leptoboea Benth. is a small genus of the family Gesneriaceae with two species and one subspecies distributed in Nepal, Bhutan, China, India, Myanmar and Thailand (Möller et al., 2017). In India, the genus is represented by two species, $L$. glabra C.B.Clarke and L. multiflora (C.B.Clarke) Benth.ex Gamble (Sinha \& Datta, 2016; Möller et al., 2017). No species of Leptoboea has so far been reported from Andaman \& Nicobar Islands (Pandey \& Diwakar, 2008; Murugan et al., 2016).

During floristic explorations in the Andaman group of Islands, a few specimens belonging to the genus Leptoboea were collected from South Andaman Island. Based on a critical study of the specimens and expert opinions received, the specimens were identified as Leptoboea multiflora (C.B.Clarke) Benth. ex Gamble subsp. grandifolia B.L.Burtt. A thorough scrutiny of the relevant literature (Clarke, 1884; Wang et al., 1998; Sinha, 1999; Burtt, 2001; Pandey \& Diwakar, 2008; Sinha \& Datta, 2016; Murugan et al., 2016; Möller et al., 2017) revealed Received: 11.02.2020; Revised \& Accepted: 20.03.2020 Published Online: 11.05 .2020 that this subspecies was hitherto unrecorded from India, but known only from Thailand. Hence, it is reported here as a new addition to the flora of India. A brief description along with photographs is provided to facilitate easy identification of this taxon.

Leptoboea multiflora (C.B.Clarke) Benth. ex Gamble subsp. grandifolia B.L.Burtt, Thai For. Bull. (Bot.) 29: 99. 2001.Type: THAILAND, Chanthaburi, Khao Phra Bat, Kathing Falls, 26.08.1972, Larsen et al. 32065 (holo AAU; iso E, $\mathrm{K})$.

Fig. 1

Perennial herbs, to $60 \mathrm{~cm}$ tall. Stems branched, spreading. Leaves opposite, oblique, serrate, equal to subequal in a pair; petioles upto $4 \mathrm{~cm}$ long; lamina elliptic to ovate, $11-14 \times 3-5 \mathrm{~cm}$, base cuneate to broadly cuneate, apex acute to acuminate, margins shallowly serrate, adaxially appressed pilose, especially along veins, abaxially appressed pubescent; lateral veins 9-12 on each side of midrib. Cymes axillary, 3-5-flowered, umbellate; peduncles 7-8 cm long, filiform, puberulent; bracts linear to subulate, $3-4 \times 0.2-0.4 \mathrm{~mm}$, puberulent. Pedicels 1.5-2 cm long, filiform, often bracteolate. Sepals 5 , linear to narrowly triangular, free to base, equal, 2.0-2.5 $\times$ 0.5-1.0 mm. Corolla shallowly campanulate, white with pink blotches on the adaxial side at the base of two upper lobes, c. $1.0 \times$ $1.5 \mathrm{~cm}$, glabrous outside; tube 4-5 mm long; limb obscurely bilabiate, lobes sub-equal, sub-orbicular to oblong, 5-6 × 4-6 mm. Stamens 4, inserted at corolla base, included; filaments $1.0-1.5 \mathrm{~mm}$ long; anthers free, c. $2 \times 1.5 \mathrm{~mm}$, basifixed, thecae subparallel, confluent at apex, dehiscing apically; staminodes sometimes present. Ovary ellipsoid, $c$. 

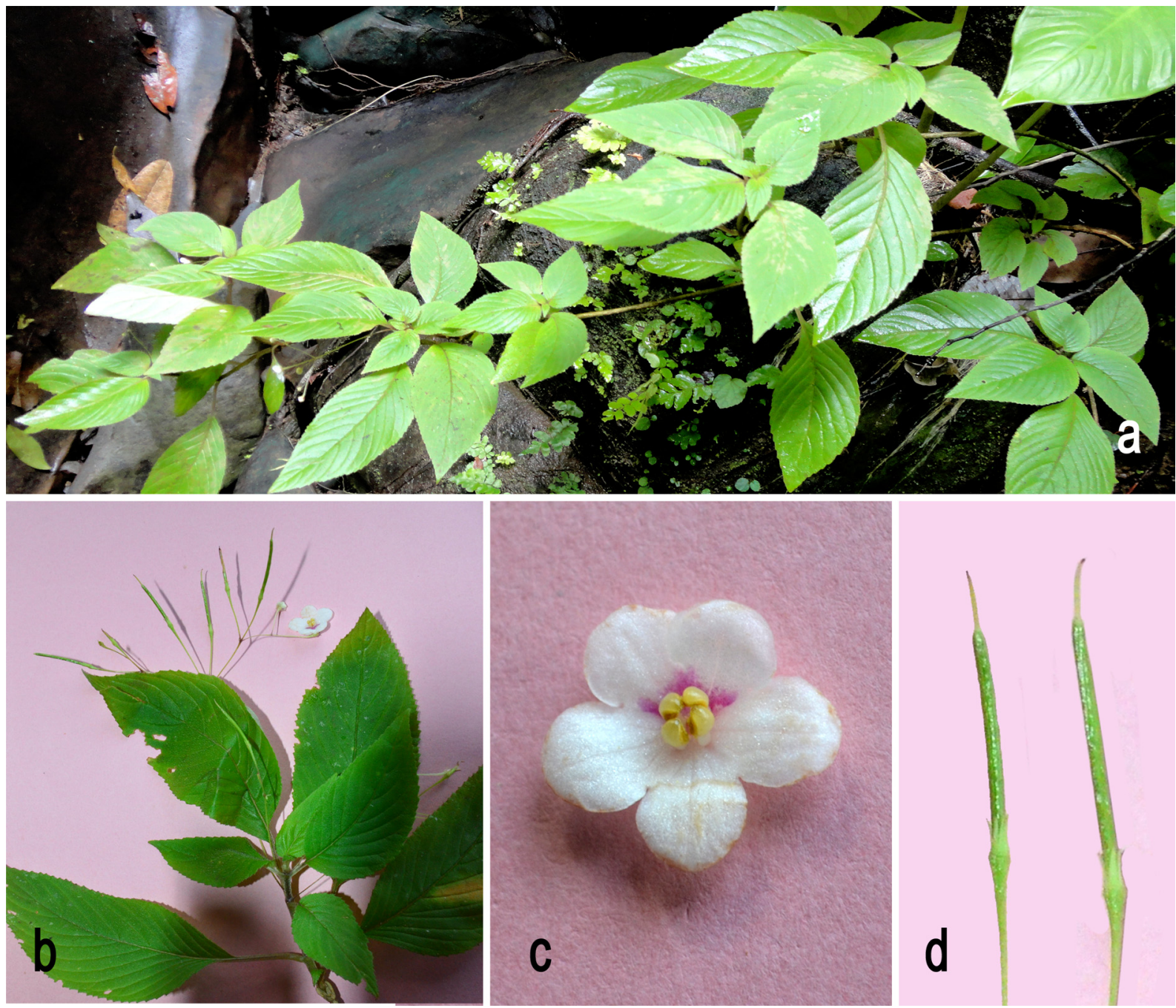

Fig. 1. Leptoboea multiflora (C.B.Clarke) Benth. ex Gamble subsp. grandifolia B.L.Burtt: a. Habit and habitat; b. Flowering and fruiting branch; c. Flower; d. Young capsules (from Joju P. Alappatt 552).

$1.5 \times 0.5 \mathrm{~mm}$, sparsely puberulent; style $4 \mathrm{~mm}$ long, glabrous; stigma capitate. Capsules straight, linear with persistent calyx and style, $1.5-2 \mathrm{~cm}$ long. Seeds minute, black.

Flowering \& fruiting: Flowering from August to September and fruiting from September to November.

Habitat: Rare in inland evergreen forests growing in shady, rather cool, humid and moist rock crevices on the sides of small perennial streams along with Globba pauciflora King ex Baker, Begonia andamensis Parish ex C.B.Clarke, Argostemma neurocalyx Miq., Boesenbergia siphonantha (King ex Baker) M.Sabu, Prasanthk. \& Skornick., Amorphophallus longistylus Kurz ex Hook.f. and Bolbitis appendiculata (Willd.)
Iwatsuki, at an elevation of about $50 \mathrm{~m}$.

Distribution: Thailand and India (South Andaman Island).

Specimens examined: INDIA, Andaman \& Nicobar Islands, South Andaman Island, Western slopes of Mt. Harriet Hill Ranges near Wrightmyo, Parachattan water falls, 26.09. 2015, Joju P. Alappatt 552 (PBL). THAILAND, Chanathaburi, Khao Khitchakut National Park, Khao Phra Bhat, 27.08.2012, David J. Middleton, P. Karaket, S. Suddee \& P. Triboun 5680 (E [E00547429 digital image]) Prachin Buri, Na Di, Khao Yai National Park, trail to Heo Narok waterfall, 20.08.2012, David J. Middleton, C. Hemrat, M. Poopath \& P. Triboun 5627 (E [E00629427 digital image]). 
Table 1. Morphological comparison of L. multiflora subsp. grandifolia with L. multiflora subsp. multiflora

\begin{tabular}{|l|l|l|}
\hline Characters & $\begin{array}{l}\text { L. multiflora (C.B.Clarke) Benth. } \\
\text { ex Gamble subsp. grandifolia B.L.Burtt }\end{array}$ & $\begin{array}{l}\text { L. multiflora (C.B.Clarke) Benth. } \\
\text { ex Gamble subsp. multiflora }\end{array}$ \\
\hline Size of leaves & $11-18 \times 3-9 \mathrm{~cm}$ & $2.5-11 \times 1.3-5 \mathrm{~cm}$ \\
\hline Position of inflorescence & Axillary to the leaves of main shoots & Axillary to the leaves of short shoots \\
\hline Dwarf shoots & Absent & Present \\
\hline
\end{tabular}

Notes: Leptoboea multiflora subsp. grandifolia differs from the other subspecies by having larger leaves and inflorescences that are axillary to the leaves of main shoots. In Leptoboea multiflora subsp. multiflora flowers are borne in inflorescences axillary to the leaves of short shoots that are themselves axillary to the leaves of the main shoot. Dwarf shoots are not formed in Leptoboea multiflora subsp. grandifolia.

Leptoboea Benth. has a relatively narrow distribution with its two species and one subspecies distributed from Nepal, Bhutan, China, India and Myanmar to Thailand. Leptoboea multiflora (C.B.Clarke) Benth. ex Gamble subsp. multiflora is reported from Nepal, Bhutan, China, India, Myanmar and Thailand while subsp. grandifolia B.L.Burtt had until now only been reported from Thailand and now from Andaman and Nicobar Islands. Leptoboea glabra C.B.Clarke is reported from Northeast India (Sikkim, West Bengal \& Assam).

There are a number of plants reported from the Andaman and Nicobar Islands that also occur in Thailand. The Andaman and Nicobar group of islands are situated between two major biodiversity hotspots, the Indian subcontinent and the Malaysian-Indonesian region (Malesia) and consequently contains floristic elements representative of the Indian, Myanmarese, Thai, and Malesian floras. For the Nicobar Islands, the flora resembles closer to that of Malesia rather than India (Balakrishnan \& Ellis, 1996).

\section{Acknowledgements}

The author is grateful to Shri. Tarun Coomar IFS, PCCF, Department of Environment \& Forests, Andaman \& Nicobar Islands and Dr. Lal Ji Singh, Botanical Survey of India, Port Blair for providing facilities and support. Thanks are due to Dr. David
Middleton, Singapore Botanic Gardens for his valuable suggestions.

\section{Literature Cited}

BALAKRISHNAN N.P. \& J.L. ELLIS 1996. Andaman \& Nicobar Islands. In: HAJRA P.K., SHARMA B.D., SANJAPPA M. \& A.R.K. SASTRY (eds.), Flora of India, Introductory Volume. Part 1. Botanical Survey of India, Kolkata. pp. 523-538.

BURTT B.L. 2001. Flora of Thailand: Annotated checklist of Gesneriaceae. Thai Forest Bulletin (Botany) 29: 81109. https://li01.tci-thaijo.org/index.php/ThaiForest Bulletin/article/view/24906

CLARKE C.B. 1884. Gesneriaceae. In: HOOKER J.D. (ed.), The Flora of British India. Volume 4. L. Reeve \& Co. Ltd., London. pp. 336-375.

MÖLLER M., NAMPY S., JANEESHA A.P. \& A.WEBER 2017. The Gesneriaceae of India: Consequences of updated generic concepts and new family classification. Rheedea 27(1): 23-41. https://dx.doi.org/10.22244/ rheedea.2017.27.1.5

MURUGAN C., PRABHU S., SATHIYASEELAN R. \& R.P. PANDEY 2016. A checklist of plants of Andaman and Nicobar Islands. ENVIS Centre on Floral Diversity, Botanical Survey of India, Howrah. Available at: http://www.bsienvis.nic.in/database/Checklist-ofAndaman-Nicobar-islands24427.aspx (Accessed on 06.02.2020)

PANDEY R.P. \& P.G. DIWAKAR 2008. An integrated checklist flora of Andaman and Nicobar Islands, India. Journal of Economic and Taxonomic Botany 32(2): 403500.

SINHA B.K. 1999. Gesneriaceae. In: HAJRA P.K. \& P.S.N. RAO (eds.), Flora of Great Nicobar Island. Botanical Survey of India, Kolkata. pp. 328-332.

SINHA, B.K. \& S. DATTA 2016. Taxonomic account on the family Gesneriaceae in Northeast India. Nelumbo 58: 1-43. https://doi.org/10.20324/nelumbo/v58/2016/ 105932

WANG W.T., PAN K.Y., LI Z.Y., WEITZMAN A.L. \& L.E. SKOG 1998. Gesneriaceae. In: WU Z.Y. \& P.H. RAVEN (eds.), Flora of China. Volume 18. Science Press, Beijing and Missouri Botanical Garden, St. Louis. pp. 244-401. 